\title{
Pembelajaran di Masa Pandemi: Tidak Hanya Metode Daring Saja
}

\author{
Ismail Suardi Wekke \\ Institut Agama Islam Negeri (IAIN) Sorong \\ Email: iswekke@gmail.com
}

\author{
Ahmad Muzawir Saleh \\ Universitas Islam Negeri (UIN) Alauddin Makassar \\ Email: ahmadmuzawirs71@gmail.com
}

Pandemi Covid-19 telah memberikan jalan baru kepada sebuah transformasi baru dalam sektor kehidupan, tak terkecuali di sektor pendidikan. Pembelajaran kini harus bertranformai dan telah terkonfirmasi oleh menteri pendidikan bahwa pembelajaran di masa pandemi akan berlangsung dengan system PJJ (Pembelajaran Jarak Jauh). Pembelajaran seperti itu tentunya akan bergantung pada tekhnologi digital atau yang biasa disebut sebagai pembelajaran e-learning.

Pembelajaran seperti itu dimaksudkan untuk memunkinkan peserta didik dapat belajar meskipun secara fisik tidak tidak hadir atau berhalangan hadir ketika proses pembelajaran terjadi di kelas (Shandyastini, N.M. \& Noviyanti, K. D. P., 2016:1). Namun, harus dipahami pula bahwa di semua literature, pembelajaran e-learning tidak semua sukses diterapkan kepada peserta didik karena di sebabkan factor lingkungan belajar ataupun karakteristik siswa. (Suni Astini M. K., 2020: 15).

Factor lingkungan belajar dan siswa itulah yang berpengaruh pada saat sekarang ini, siswa yang berada pada pelosok desa dengan kondisi keluarga yang serba terbatas dalam hal pendidikan maupun tekhnologi tentunya akan berbeda dengan siswa yang berada di kota dengan pendidikan kelurga yang baik dalam mengakses pembelajaran online tersebut.

Semisal, yang terjadi di sebuah kelas di Kabupaten Sinjai, dari 13 murid, hanya 3 orang yang dapat mengikuti pembelajaran daring. Selebihnya, keterbatasan media gawai dan juga akses internet yang tidak memungkinkan untuk tetap mengikuti pembelajaran.

Dari tiga orang yang mengikuti pembelajaran, tak lebih soal keberuntungan semata. Di rumah, mereka dianuegrahi kakak yang baru saja lulus sekolah menangah atas. Sementara menunggu ujian dan juga studi lanjut ke perguruan tinggi, Sang Kakaklah yang membantu adiknya untuk belajar.

Sementara itu, orang tua sudah mulai protes. Mereka meminta sekolah dibuka. Sekalipun itu di zona kuning, masyarakat ada yang menuntut untuk dibukanya sekolah. Hal tersebut didasari atas pemikiran orang tua yang mengkhawatirkan anaknya tidak dapat terus belajar sehingga bisa saja akan menjadi tertinggal dalam persoalan pembelajaran.

Kondisi ini menjadi agenda bersama. Betapa pandemi dan juga pendidikan, harus disinkronisasi. Pada saat yang sama, penyebaran wabah menjadi perhatian dan dengan tetap menutup sekolah merupakan pilihan darurat. Keselamatan, dan juga menghentikan penyebaran virus merupakan pilihan utama. Sementara untuk proses pembelajaran pelbagai ragam pembelajaran dapat dilakukan.

Tentu saja tidak dapat pula dipungkiri bahwa era digitalisasi pembelajaran harus mulai di biasakan.Namun, transformasi tiba-tiba seperti sekarang ini kemudian akan menimbulkan permasalahan baru yang disebabkan tidak adanya persiapan lebih awal. Olehnya, dalam kondisi ini, ada ragam alternatif yang dapat digunakan, dengan tidak semata-mata hanya bertumpu metode daring saja. Berikut beberapa praktik yang dapat dijadikan referensi. 
Pertama, pembelajaran kontekstual. Pengalaman dan juga kesempatan mengalami sebuah kondisi tertentu. Ketika masyarakat berada di lingkungan pesisir, maka anak dapat ikut serta mengikuti aktivitas orang tua. Ikut melaut, menjadi nelayan.

Justru, ini menjadi kesempatan untuk belajar. Demikian pula ketika orang tua dengan profesi petani. Maka, anak turut turun ke sawah. Belajar tak harus di depan buku saja, namun dengan berada di alam secara langsung, merupakan proses belajar juga. Pembelajaran seperti itu justru akan lebih mendekatkan peserta didik dengan kehidupan sehari-harinya sehingga ia akan lebih mengerti sebab terjadi hubungan langsung dengan apa yang di pelajari disekolah dengan apa yang dilakukannya dalam khidupan.

Kedua, kunjungan belajar. Guru dapat melakukan kunjungan ke rumah dengan skala kelas yang terbatas. Sebagaimana dilaksanakan guru-guru di Kabupaten Sidrap, Sulawesi Selatan. Guru melaksanakan kunjungan untuk menyapa murid-murid, sekaligus melaksanakan pembelajaran.

Ketiga, pembelajaran dengan media cetak. Koran cetak, ataupun bahan bacaan lainnya dapat didistribusikan secara berkala melalui jalur administrasi pemerintahan yang sudah mapan. Sehingga murid atau siswa secara berkala mendapatkan bahan belajar dan juga tetap melaksanakan pembelajaran.

Satu hal lagi, pada diksi tugas. Selama ini murid ataupun siswa merasa terbebani. Sehingga perlu dialihkan menjadi kata latihan. Pelaksanaan latihan semata-mata untuk kepentingan murid. Bukan untuk kepentingan guru. Adapun guru sebagai fasilitator untuk melaksanakan pembelajaran. Peserta didik, dengan sukarela akan melaksanakan. Ini terkait dengan kepentingan mereka untuk menguasai capaian pembelajaran.

Akhirnya, guru ataupun dosen, serta fungsi-fungsi Pendidikan lainnya harus kreatif untuk mengatasi masalah. Tidak semata-mata hanya pada soal daring saja. Sehingga tidak ada satupun warga bangsa yang tidak ikut serta dalam proses pembelajaran.

Kondisi ini menjadikan katalisator untuk pendidikan digital (Mulyono \& Wekke, 2018) terwujud. Namun, pada saat yang sama kita mengalami kendala terkait infrastruktur Pendidikan.

\section{Daftar Pustaka}

Astini, Ni Komang Suni. 2020. Pemanfaatan Tekhnologi Informasi dalam Pembelajaran Tingkat Sekolah Dasar Pada Masa Pandemi Covid-19. Jurnal Lampuhyang, 11 (2).

Mulyono, H., \& Wekke, I. S. (2018). Strategi Pembelajaran di Abad Digital. Yogyakarta: Penerbit Gawe Buku.

Shandyastini, Ni Made \& Novianti, Kadek Dwi Pradnyani. 2016. Analisisi E-Learning STMIK STIKOM Bali Menggunakan Technology Acceptance Model. Jurnal TEKNOIF, 4 (2). 